\title{
Mantle-shell complex reactions elicited by digenean metacercariae in Gaimardia trapesina (Bivalvia: Gaimardiidae) from the Southwestern Atlantic Ocean and Magellan Strait
}

\author{
Cristián F. Ituarte ${ }^{1, *}$, Florencia Cremonte ${ }^{2}$, Guillermo Deferrari ${ }^{3}$ \\ ${ }^{1}$ División Zoología Invertebrados, Museo de La Plata, 1900 La Plata, Buenos Aires, Argentina \\ ${ }^{2}$ CEPAVE (Centro de Estudios Parasitológicos y de Vectores), 2 No. 584, 1900 La Plata, Buenos Aires, Argentina \\ ${ }^{3}$ CADIC (Centro Austral de Investigaciones Científicas), Ushuaia, Tierra del Fuego, Argentina
}

\begin{abstract}
The host response to 3 different larval digeneans affecting Southwestern Atlantic and Magellanic populations of the bivalve Gaimardia trapesina (Lamarck, 1819) (Gaimardiidae) is described. Unencysted metacercariae of 2 species of Gymnophallidae and 1 species of Lepocreadiidae co-exist in the peripheral and general extrapallial spaces. Differences in host responses to stimuli generated by each parasite are described. Infections by Gymnophallidae gen. sp. 1 metacercariae elicit a mantle-shell complex reaction involving both alteration of the mantle epithelium (hyperplasia and metaplasia) and calcium carbonate deposition to form an incomplete calcareous covering of single larvae, comprising individual crystallites in an organic matrix. The calcareous covering covers only the posterior two-thirds of the larval body, having its anterior end free in the extrapallial space, which ensures survival of the larvae. The peculiar features of the host response result from a successful process of adjustment to the parasite's life cycle. Metacercariae of Gymnophallidae gen. sp. 2 occur in one or more small groups of up to 30 individuals, either in the general or in the peripheral extrapallial spaces. The outer mantle reaction includes hyperplasia and metaplasia of the epithelium adjacent to the larvae. Deposition of calcium carbonate did not occur. Lepocreadiidae gen. sp. metacercariae were observed exclusively in the general extrapallial space lodged in single shallow pits whose shape fit the parasite's body shape and size. In simultaneous infections, metacercariae of Gymnophallidae and Lepocreadiidae elicited different responses in an individual, which suggests that each parasitic entity involves a different stimulus to the host.
\end{abstract}

KEY WORDS: Bivalvia $\cdot$ Pathology $\cdot$ Digenetic trematoda $\cdot$ Metacercariae $\cdot$ Host reaction

\section{INTRODUCTION}

The information on marine bivalve diseases is extraordinarily large and mainly deals with microbial and protozoal disease agents in species of economic importance. With respect to digenetic trematoda, they have been registered from almost every marine bivalve species, but unfortunately, parasitologists have focussed

*E-mail: cituarte@museo.fcnym.unlp.edu.ar their attention primarily on taxonomic aspects (Lauckner 1983). Among the literature regarding the pathology of trematode metacercariae in marine bivalves, some remarkable examples are given by Bartoli (1967, 1973, 1974, 1978), Bartoli \& Prévot (1978), Campbell (1985) and Bowers et al. (1996).

Studies on larval digenean populations affecting bivalves in the Southwestern Atlantic Ocean are scarce. First records were reported by Szidat $(1962,1965)$, who described the Gymnophallidae Parvatrema australis (Szidat, 1962) from Mytilus edulis platensis (Mytilidae). 
Cremonte (1999) reported 7 metacercariae identified only to the family level (5 species of Gymnophallidae, 1 Renicolidae and 1 Monorchiidae) from intertidal bivalve populations. Finally, another gymnophallid metacercariae record was made by Martorelli \& Morriconi (1998) from gastropods.

Gaimardia trapesina (Lamarck, 1819) is a common bivalve species that lives attached by a strong byssus to the giant kelp Macrocystis pyrifera (Linnaeus) (locally known as 'Cachiyuyo'). In the southwestern Atlantic Ocean the species ranges from Santa Catarina (Brazil) to the Magellanic Region (Rios 1994). Presently nothing is known about the parasites infecting this bivalve.

During a study of the reproductive biology of Gaimardia trapesina from the Magellan Strait at Ushuaia, Tierra del Fuego, Argentina, larval digeneans (metacercariae) and certain unusual host reactions were discovered. Our aim is to describe the characteristics of the mantle-shell complex reaction mounted against invasive larvae and to study the host response at both the individual and cellular levels. The variations in the composition of the larval digenean associations found parasitizing G. trapesina with respect to time and geographic location, and the diversity in the host responses to different parasitic entities are also described.

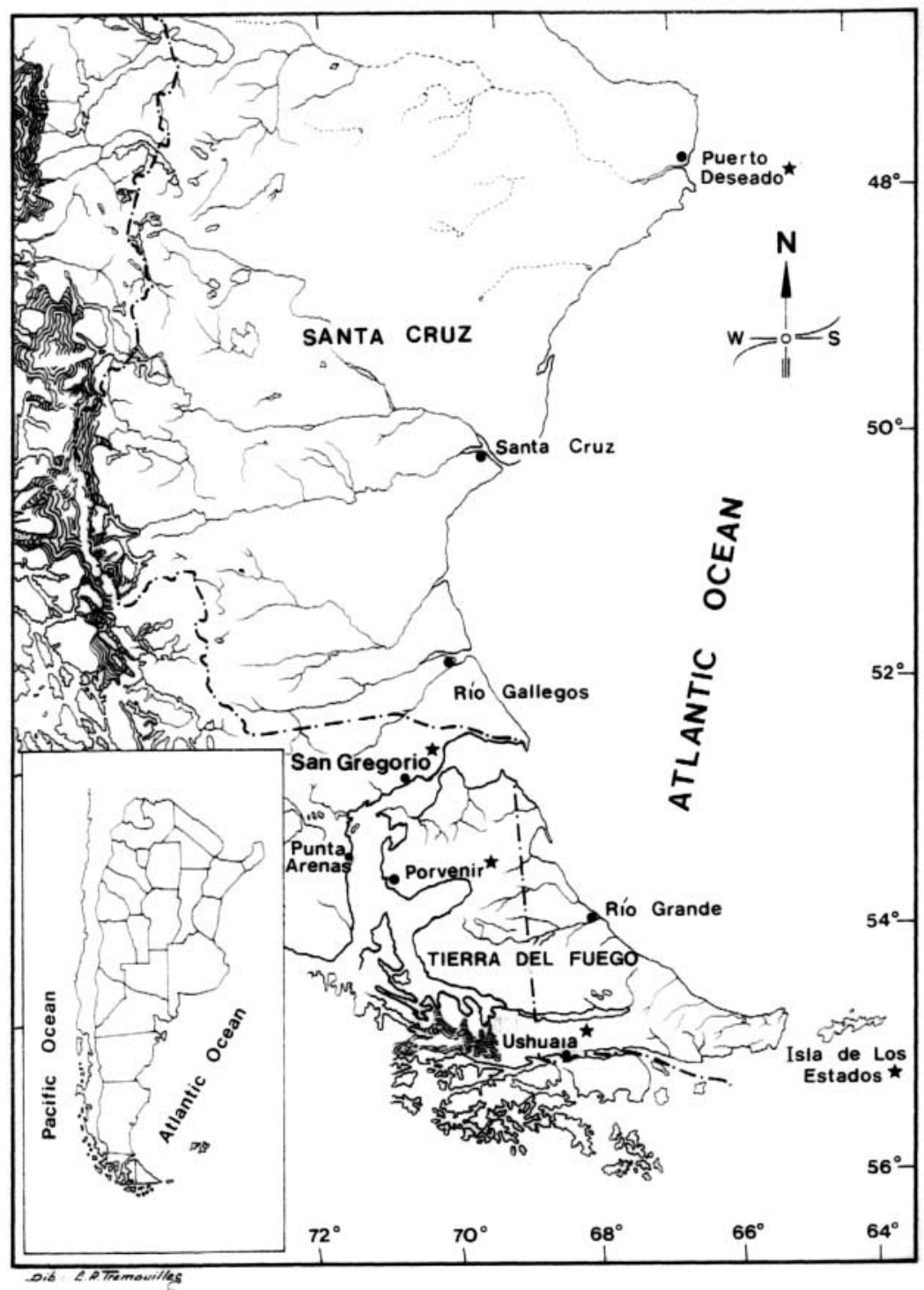

Fig. 1. Location map (sampling localities marked with a star)

\section{MATERIALS AND METHODS}

Specimens of Gaimardia trapesina were collected from the Beagle Channel at Ushuaia $\left(54^{\circ} 48^{\prime} \mathrm{S}, 68^{\circ} 19^{\prime} \mathrm{W}\right)$ Tierra del Fuego, Argentina (Fig. 1) in January, February, May and July of 1997. Immediately after collection bivalves were immersed either in Bouin's fluid or $80 \%$ ethanol. This procedure, performed to analyze the reproductive process of G. trapesina, restricted larvae identification to family level. Metacercariae were removed, stored in $70 \%$ alcohol, stained with Semichon's acetocarmine, cleared in creosote, mounted in Canada balsam and measured. Drawings were made with the aid of a camera lucida. Measurements of 10 specimens shown in the tables, are given in micrometers with the range followed by the mean in parentheses. Twenty
G. trapesina specimens from each month were examined for parasites. Due to the high intensity of infection, larval counts were performed on a half of each individual bivalve and the results multiplied by 2 for indices calculations. Parasitological indices and related terminology follow Bush et al. (1997). Nomenclature regarding metacercaria habitats in the extrapallial spaces follows Bartoli (1974).

Valves of specimens used for the scanning electron microscope (SEM) study were treated for 5 min with a $10 \%$ solution of commercial sodium hypochlorite and rinsed in distilled water prior to mounting and coating for observation. Specimens used for histological study were decalcified by $24 \mathrm{~h}$ rinse in Raillet Henry fixative. Portions of the mantle and periostracum containing digenean larvae were sectioned prior to dehydrating, 
embedding in paraffin, sectioning ( $7 \mu \mathrm{m}$ thick) and staining with hematoxylin-eosin (Gabe 1968).

Mineralogical analysis of shells of Gaimardia trapesina and calcareous coverings of metacercariae were made using a standard X-ray diffractometer. For this purpose, 100 calcareous coverings were detached from inner shell surface with the aid of a steel blade.

Additional samples were obtained from San Gregorio and Porvenir, on the Chilean shore of the Magellan Strait, and from Puerto Deseado (47 $\left.44^{\prime} \mathrm{S}, 65^{\circ} 54^{\prime} \mathrm{W}\right)$, Province of Santa Cruz, Argentina (Fig. 1). Museum specimens from Isla de los Estados (54 $\left.46^{\prime} \mathrm{S}, 64^{\circ} 18^{\prime} \mathrm{W}\right)$ (Fig. 1) were also examined for parasites.

\section{RESULTS}

Three species of larval digenean trematodes belonging to the families Gymnophallidae (2 species) and Lepocreadiidae (1 species) were found. The only larval stage represented was the metacercaria. The larvae will be referred to as Gymnophallidae gen. sp. 1, Gymnophallidae gen. sp. 2 and Lepocreadiidae gen. sp. All materials were housed in the malacological and helminthological collections at the Division of Invertebrates, Museo de La Plata (MLP), Argentina under the registration numbers: Helminthology: MLP 4788/90; Malacology: MLP 4366, 4367, 5249, 5266, 5321, 5322, 5574,5575 .

\section{Metacercaria Gymnophallidae gen. sp. 1 (Fig. 2a)}

Diagnostic characters. Body small and elongate, spinose. Oral sucker subterminal, twice as large as ventral sucker. Prepharynx absent; pharynx present. Oesophagus long, caeca dilated. Ventral sucker located in the posterior third of the body. Testes opposite or slightly diagonal, located at the level of, or slightly posterior to ventral sucker. Ovary post-testicular. Vitelline glands in one follicular mass overlapping ventral sucker. Excretory vesicle Y-shaped. Measurements are given in Table 1. Prevalence and mean intensity of infection values are given in Table 2.

Comments. The diagnostic characters allow inclusion of the studied metacercariae in the Gymnophallidae. However, the position of the ovary (i.e. ovary post-testicular) is unusual for the family, the only other

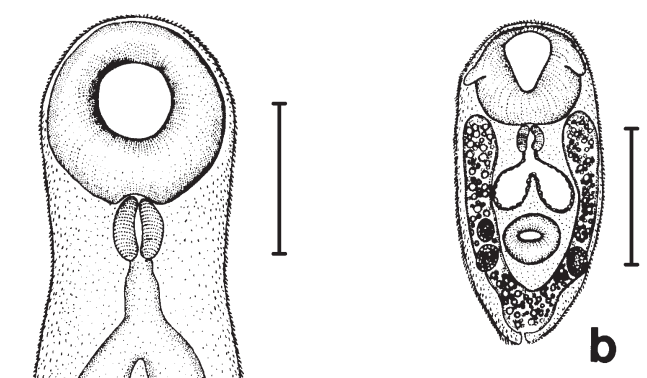

Fig. 2. Digenean metacercariae from Gaimardia trapesina. (a) Gymnophallidae gen. sp. 1, ventral view; (b) Gymnophallidae gen. sp. 2, ventral view; (c) Lepocreadiidae gen. sp., ventral view. Scale bars = $100 \mu \mathrm{m}$

exception being the monotypic genus Pseudogymnophallus Hoberg, 1981, in which the ovary is located between the testes. The elongated body is also an unusual feature for Gymnophallidae (James 1964, Bartoli 1974).

Table 1. Morphological comparison and measurements $(\mu \mathrm{m})$ of Gymnophallidae metacercariae from Gaimardia trapesina from Ushuaia, Tierra del fuego, Argentina

\begin{tabular}{|lll|}
\hline & $\begin{array}{l}\text { Gymnophallidae } \\
\text { gen. sp. 1 }\end{array}$ & $\begin{array}{l}\text { Gymnophallidae } \\
\text { gen. sp. 2 }\end{array}$ \\
\hline Body size and shape & Small, elongate & $\begin{array}{l}\text { Minute, ovoid } \\
\text { Body length }\end{array}$ \\
Body width & $138-458(438)$ & $89-116(215)$ \\
Oral sucker (Os) & $110-137(154)$ & $57-71(67) \times 58-70(71)$ \\
Os lateral projections & Absent & Present \\
Ventral sucker (Vs) & $32-70(46) \times 55-67(59)$ & $31-37(34) \times 33-42(37)$ \\
Pharynx & $30-45(38) \times 32-41(37)$ & $21-27(23) \times 20-27(23)$ \\
Oesophagus & $32-70(46)$ & $9-11(10)$ \\
Caeca & $82-176(128) \times 32-52(42)$ & $27-45(37) \times 23-32(29)$ \\
Right testis & $29-46(37) \times 22-35(31)$ & $20-31(26) \times 15-26(19)$ \\
Left testis & $30-41(36) \times 26-36(31)$ & $22-31(26) \times 13-19(17)$ \\
Ovary & $20-34(26) \times 20-30(23)$ & $13-20(17) \times 13-21(15)$ \\
Ovary position & Post-testicular & Pre-testicular \\
Vitelline glands & Follicular & Not seen \\
Pre-acetabular space & $222-360(280)$ & $100-140(124)$ \\
1/(Os length/Vs length) & $1: 0.46$ & $1: 0.51$ \\
\hline
\end{tabular}


Table 2. Prevalence (P) and mean intensity (I) of metacercaria infections in Gaimardia trapesina from Ushuaia during 1997

\begin{tabular}{|c|c|c|c|c|c|c|c|c|}
\hline \multirow[b]{2}{*}{ Parasitological indices } & \multicolumn{2}{|c|}{ January } & \multicolumn{2}{|c|}{ February } & \multicolumn{2}{|c|}{ May } & \multicolumn{2}{|c|}{ July } \\
\hline & $\mathrm{P}$ & $\mathrm{I}$ & $\mathrm{P}$ & I & $\mathrm{P}$ & $\mathrm{I}$ & & $\mathrm{I}$ \\
\hline Gymnophallidae gen. sp. 1 & 0 & - & 15 & 2 & $100^{\mathrm{a}}$ & 15.7 & $100^{\mathrm{a}}$ & 23 \\
\hline Gymnophallidae gen. sp. 2 & 0 & - & 30 & 1.5 & 100 & 22.4 & 100 & 72 \\
\hline Lepocreadiidae gen. sp. & 25 & 1.2 & 5 & 1 & 15.4 & 1.5 & 10 & 3 \\
\hline
\end{tabular}

Habitat. Whole general extrapallial space; in cases of moderate infections $(<10$ larvae per valve) a preference for the upper third of the extrapallial space was evident. Less frequently they occurred in the peripheral extrapallial space (Table 2).

Localities. Southwestern Atlantic Ocean at Puerto Deseado and Isla de los Estados, Beagle Channel at Ushuaia (Argentina), and Magellan Strait at San Gregorio (Chile) (Fig. 1).

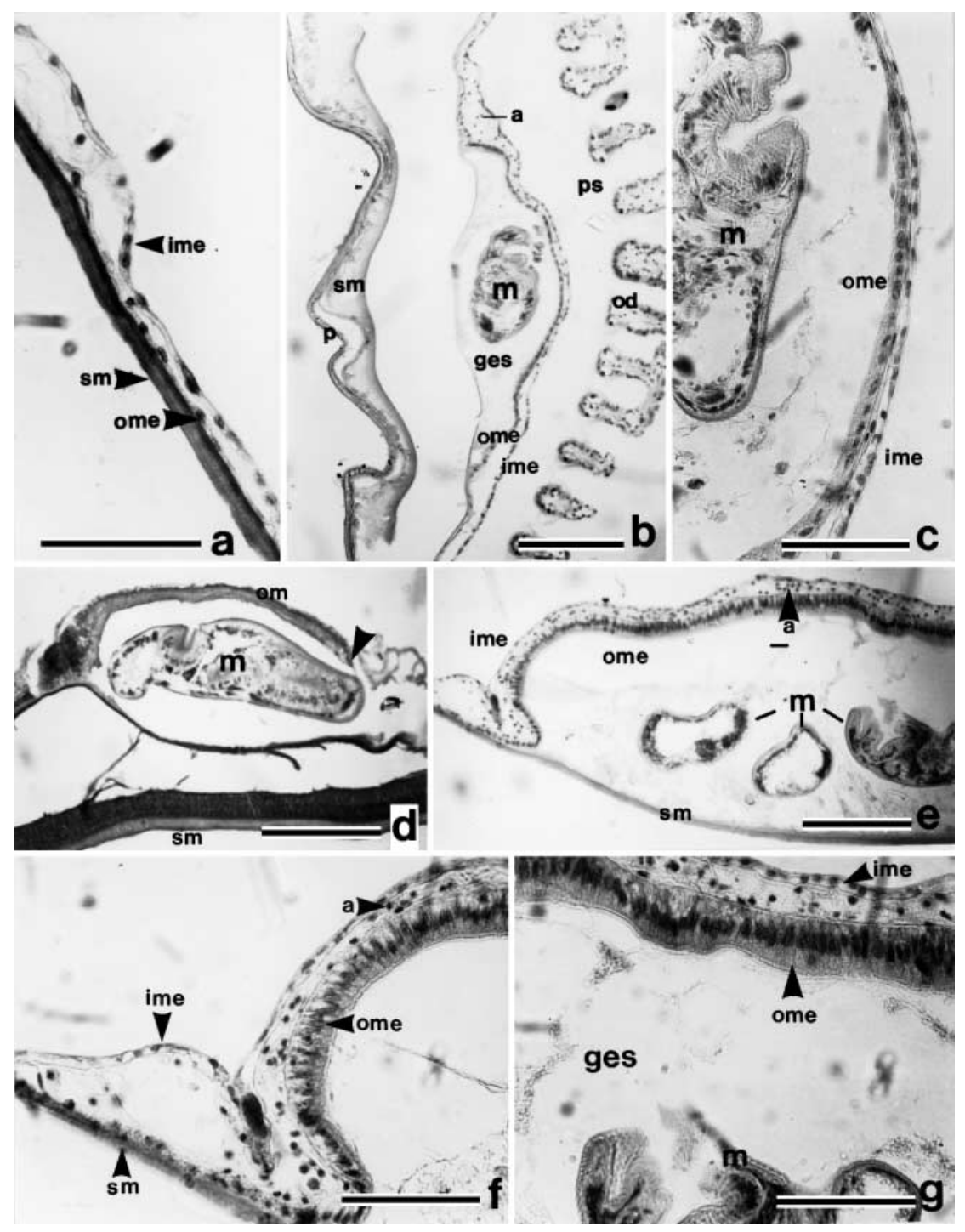

Fig. 3. Reaction of Gaimardia trapesina to Gymnophallidae metacercariae. (a) Normal mantle epithelium and organic shell matrix; (b-d) Reaction to Gymnophallidae gen. sp. 1. (b) Metacercaria in the general extrapallial space covered by the altered mantle epithelium (the space between shell matrix and mantle epithelium is an artifact due to decalcification procedure); (c) Detail of outer mantle epithelium showing hyperplasia and metaplasia; (d) Longitudinal section of a larva showing the lack of organic matrix (arrowhead) at the anterior end of the covering; (e-g) Reaction to Gymnophallidae gen. sp. 2. (e) Three larvae in the general extrapallial space covered by modified mantle epithelium; (f) Detail of the transitional zone between normal (left) and modiefied (right) mantle epithelium; (g) Metaplasia and hyperplasia in the outer mantle epithelium. a: amoebocytes; ges: general extrapallial space; ime: inner mantle epithelium; m: metacercaria; od: outer demibranch; om: organic matrix of calcareous covering; ome: outer mantle epithelium; p: periostracum; ps: pallial space; sm: shell matrix. Scale bars: (a) =10 $\mu m_{\text {; }}(\mathrm{b}),(\mathrm{d})=100 \mu \mathrm{m} ;(\mathrm{c}),(\mathrm{f}-\mathrm{g})=50 \mu \mathrm{m}$; $(\mathrm{e})=1000 \mu \mathrm{m}$ 
Host response to metacercaria Gymnophallidae gen. sp. 1. The host reaction was characterized by mantle epithelium and shell alterations from the normal condition shown in Fig. 3a. The outer layer of the mantle epithelium adjacent to the larvae showed a proliferative reaction to form a dome-shaped covering (Fig. 3b). Furthermore, the shape of the mantle cells changed, becoming cubic (5 $\mu \mathrm{m}$ tall) (Fig. 3c). The inner mantle layer was normal. The number of amoebocytes usually present between both mantle layers showed moderate increase in the proximity of the modified area of the mantle (Fig. 3b).

A calcareous igloo-shaped covering was secreted, surrounding each larva (Fig. 4a,b,e). The calcareous covering always showed a lateral, slightly flattened, circular opening (125 to $150 \mu \mathrm{m}$ in diameter) through which the anterior end of the larva is exposed (Fig. 4b). The interior of the calcareous covering was tubular, slightly enlarged at the posterior end, fitting the transverse section of the larvae. The outer size, somewhat variable (Fig. 4a) ranged from 500 to $740 \mu \mathrm{m}$ in maximum diameter (in accordance with the anteroposterior axis of the larvae), the height (only determined in 1 specimen) was approximately $210 \mu \mathrm{m}$. The mineralogic analysis of the calcareous covering demonstrated its exclusively aragonitic composition (see Fig. 6).

The host reaction started after the metacercariae settled on the inner shell surface. The metacercariae were always orientated with the anterior end exposed to the extrapallial space and the oral sucker facing the mantle epithelium (Figs $3 b, c \& 4 b$ ). The early stages of the host reaction were distinguished by a slight opacity in the mantle just over the parasites, and a halo formed on the inner shell surface surrounding the larvae. Subsequently, deposition of calcium carbonate occurred in the form of fibrous-like aragonite crystals to build an oval 'basal plate' or platform (Fig. 4c,f) tightly adhered
Fig. 4. Reaction of Gaimardia trapesina to Gymnophallidae gen. sp. 1. (a) Two iglooshaped calcareous coverings on the inner surface of a shell. (b) Metacercaria lodged in living position into a calcareous covering; (c) Early stage of host reaction (the larva was dislodged during the SEM mounting procedure); (d) Detail of the aperture of a calcareous covering; (e) Upper view of an 'igloo' showing the area lacking of calcareous deposition (arrowhead); (f) Transitional zone between basal plate (with fibrous-like aragonite crystals) and the 'igloo' wall. am: amorphous calcareous material; bp: basal plate; m: metacercaria; ss: shell surface; w: 'igloo' wall. Scale bars: (a) $=500 \mu \mathrm{m}$; $(\mathrm{b}-\mathrm{e})=100 \mu \mathrm{m}$; (f) $=50 \mu \mathrm{m}$
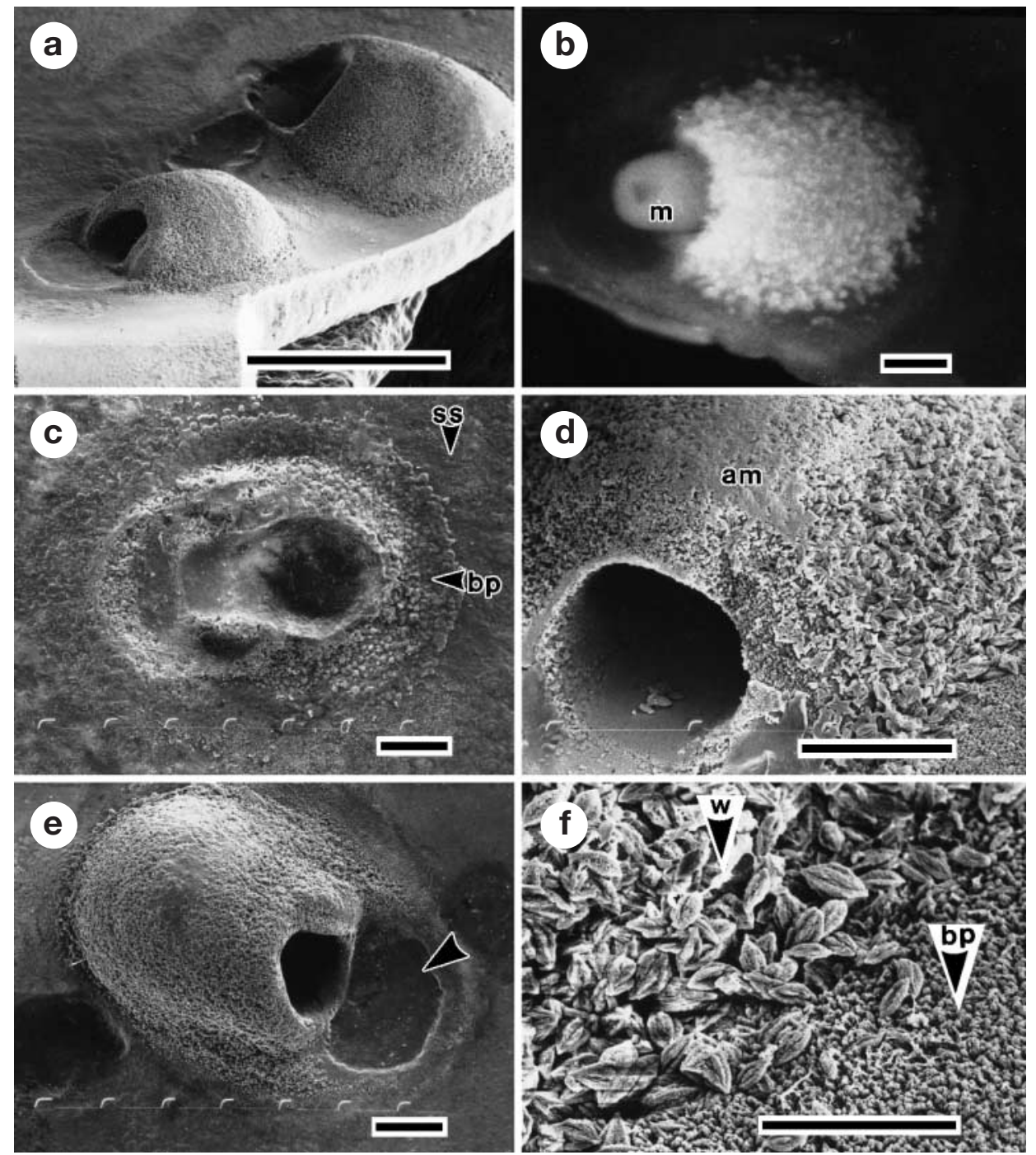
to the inner shell surface. In this form, the normal shell structure of 2 layers of aragonite microcrystals separated by a thin prismatic pallial myostracum (Figs 5b,d, \& 6) was modified by the addition of a third layer (40 $\mu \mathrm{m}$ thick at its tallest part, tapering to the sides as shown in Fig. 5b) just below the site that the parasite occupies (Fig. 5b,d). The central area of this platform, i.e. the place where the parasite lies, took the form of a short bottle or jar and was slightly sunken in the middle (Figs 4c \& 5a,d). A clearly marked oval area where calcareous deposition did not take place appeared just below the position of the anterior end of the metacercaria (Fig. 4a,b,e). As the reaction proceeded, single aragonite crystals were deposited (Fig. 5c,e), starting at the periphery of the basal platform (Fig. 4c) proceeding towards the center of the future igloo-shaped covering. The wall continued to grow until the igloo or dome-shaped calcareous covering was complete. Frequently, a deposition of amorphous calcium carbonate was observed over the layer of single crystals (Fig. 4d).
In histological sections obtained from decalcified specimens, the occurrence of a well-developed basophilic organic matrix was seen. The organic matrix, $12.5 \mu \mathrm{m}$ thick, incompletely surrounded the larval body; it was always absent at the anterior end, the aperture of the calcareous covering (Fig. 3d). The organic matrix also developed at the base of the calcareous covering, separated from that corresponding to the shell (Fig. 3d).

Metacercaria Gymnophallidae gen. sp. 2 (Fig. 2b)

Diagnostic characters. Body minute, ovoid, spinose. Oral sucker subterminal, twice as large as ventral sucker, with lateral projections. Prepharynx absent, pharynx present. Dilated caeca. Ventral sucker located in the posterior third of the body. Testes opposite or slightly diagonal, located at level of ventral sucker or slightly posterior to it. Ovary pre-testicular, rounded. Excretory vesicle Y-shaped, with a short stem and
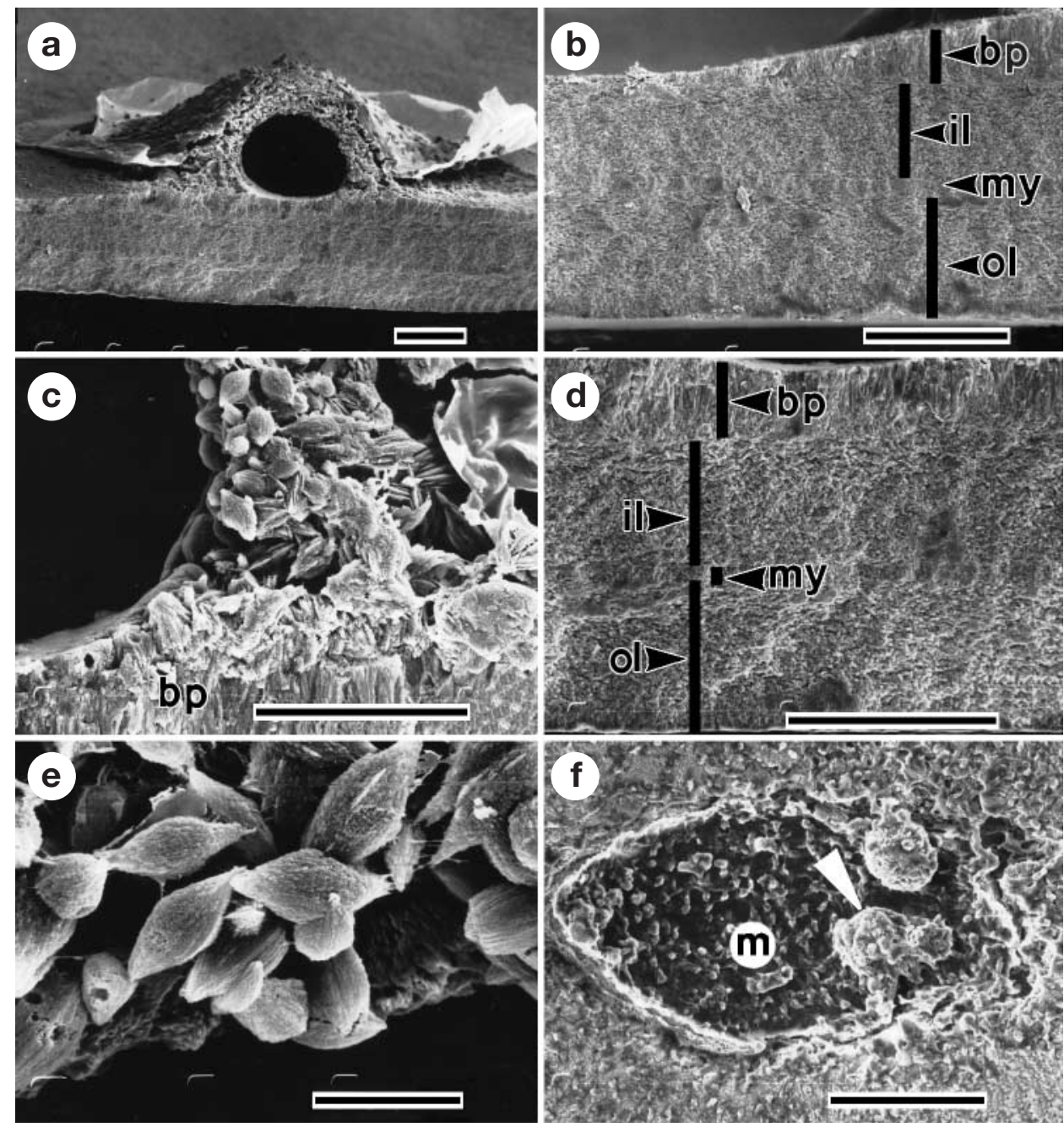

Fig. 5. (e-f) Reaction of Gaimardia trapesina to Gymnophallidae gen. sp. 1 . (a) Transverse section (by fracture) of a shell and calcareous covering; (b) Microstructure of basal plate of calcareous covering and shell wall (note the tapering of basal plate to the left); (c) Microstructure of basal plate and wall of calcareous covering; (d) Detail of basal plate microstructure; (e) Aragonite crystals from the lateral wall of calcareous covering; (f) Lepocreadiidae gen. sp. metacercaria lodged in a shell pit, partially covered by calcareous material (arrowhead). i.l.: inner shell layer; bp: basal plate; my: myostracum; m: metacercaria; ol: outer shell layer. Scale bars: $(a-b),(d),(f)=$ $100 \mu \mathrm{m}_{i}(\mathrm{c})=50 \mu \mathrm{m}_{\text {; }}(\mathrm{e})=$ $10 \mu \mathrm{m}_{\text {; }}$ 


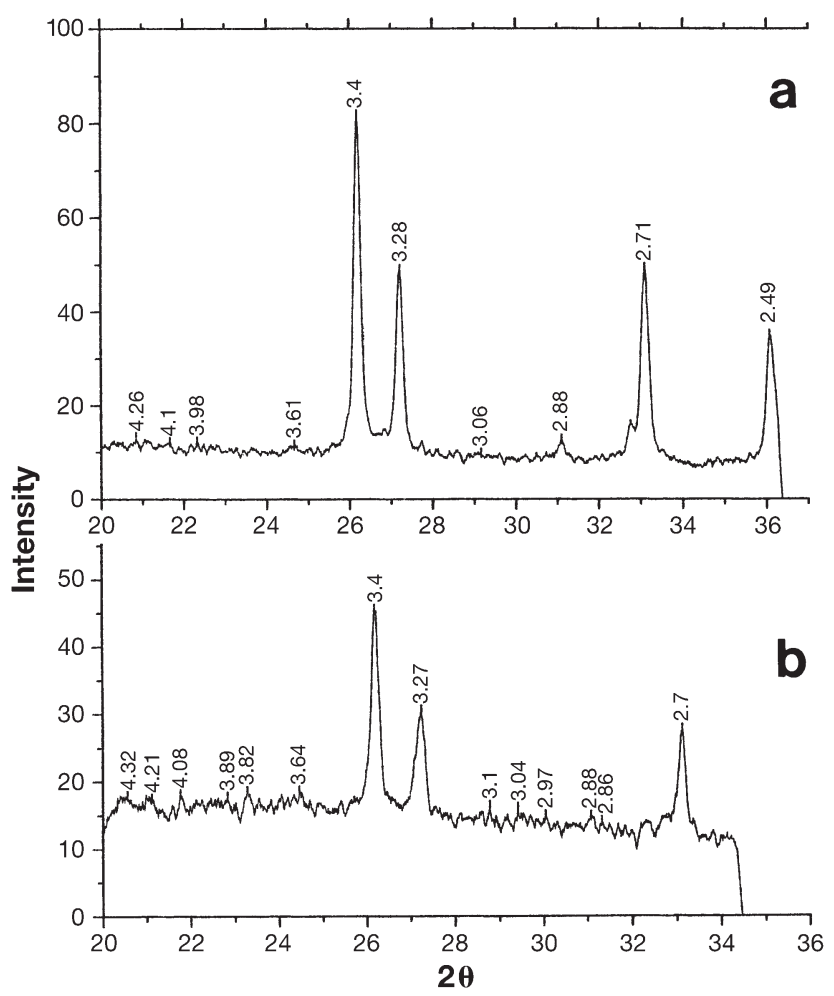

Fig. 6. Diagrams of X-ray diffraction analysis of (a) Gaimardia trapesina shells and (b) calcareous coverings of metacercaria Gymnophallidae gen. sp. 1. Numbers indicate major peaks of intensity of reflection corresponding to aragonite

dilated branches reaching the pharynx level, filled with excretory granules. Measurements are given in Table 1. Prevalence and mean intensity of infection values are given in Table 2 .

Habitat. Whole general and peripheral extrapallial spaces. In low and moderate infections a preference for the sides of the adductor muscles, and just below the umbones in the general extrapallial space, and at the center of the peripheral extrapallial space was evident.

Localities. Southwestern Atlantic Ocean at Puerto Deseado and Beagle Channel at Ushuaia, Argentina; Magellan Strait at San Gregorio, Chile (Fig. 1).

Host response to metacercaria Gymnophallidae gen. sp. 2. The host response consisted of hyperplasia and metaplasia of the outer mantle epithelium adjacent to metacercariae which were found in groups of up to 30 individuals, orientated predominantly with their ventral surfaces facing towards the mantle (Fig. 3e). The outer epithelium proliferated, leaving a relatively large space between the shell and the mantle where the larvae were located. The epithelium adjacent to the larvae became columnar (Fig. 3f,g); the cell size was approx. $25 \mu \mathrm{m}$ tall and $4.5 \mu \mathrm{m}$ wide, showing a central nucleus; the distal cytoplasm was filled with fine acidophilic secretory granules. Calcium carbonate deposition did not occur.
Metacercaria Lepocreadiidae gen. sp. (Fig. 2c)

Diagnostic characters. (Based on 20 specimens, too contracted for useful measurements.) Body oval, spinose, oculate. Ocelli formed by 2 compact masses of irregular outline located at sides of pharynx. Oral sucker subterminal. Prepharynx short, pharynx ovoid. Oesophagus long. Caeca bifurcating immediately anterior to ventral sucker, reaching almost to the posterior end of the body. Ventral sucker located in equatorial part of body. Primordia of testes in tandem, behind ventral sucker. Ovary pre-testicular, median. Excretory vesicle I-shaped, with anterior end curved on ventral sucker and overlapping it and filled with excretory granules.

Localities. Beagle Channel at Ushuaia, (Argentina) and Magellan Strait at San Gregorio, (Chile) (Fig. 1).

Habitat. In the general extrapallial space, lodged in oval or slightly elongated shallow pits.

Host response to metacercaria Lepocreadiidae gen. sp. Lepocreadiid metacercariae were observed only in the general extrapallial space with the ventral surfaces facing the mantle epithelium and lodged in wide, rounded, or slightly oval, shallow pits. The metacercariae were extremely flat, fitting perfectly into the pits (Fig. 5f). Frequently, the larvae appeared calcified and they could not be separated from their pits. Low intensities of infection precluded the histological analysis of any host tissue reaction.

\section{DISCUSSION}

Bivalves are the main hosts for metacercariae of gymnophallids (Bartoli 1974). Gymnophallid metacercariae always occur between the mantle and the valve, either free or enveloped by host tissues. Different host reactions, from lack of host response to severe lesions, have been attributed to Gymnophallidae (Cheng \& Rifkin 1970, Lauckner 1983).

In Gaimardia trapesina, not all parasites, despite occuping the same location in the host, i.e. the general and peripheral extrapallial spaces, evoke the same host reaction. Each parasitic entity evokes its own stimulus which elicits different responses from the bivalve host. The response against metacercaria Gymnophallidae gen. sp. 1 leads to the alteration of the mantle epithelium and the deposition of a calcareous covering; the reaction to metacercaria Gymnophallidae gen. sp. 2 results only in the modification of the outer mantle epithelium without deposition of calcium carbonate, while Lepocreadiidae metacercariae lead to formation of shell pits.

The reaction of the mantle-shell complex of Gaimardia trapesina, elicited by the presence of metacercaria 
Gymnophallidae gen. sp. 1 in the extrapallial space, appears to be unique among bivalve host reactions involving calcareous deposition. The reported reaction differs strikingly from the process described as nacrezation (Cheng \& Rifkin 1970) in the following aspects: (1) There is no formation of a pearl sac, i.e. an invagination of the mantle tissue that completely surrounds the parasite prior to starting the calcareous deposition. (2) From a mineralogical point of view, the type of crystals of pearls or 'blisters' are always identical to those forming the inner surface of the shell, the nacreous layer (i.e. aragonitic microcrystals). (3) The parasite larvae, subsequent to host reaction, always die. (4) Nacrezation was considered by Cheng \& Rifkin (1970) as a non immunological response, because a similar process may be elicited by a stimulus from any foreign material, living or non living.

Among the metacercariae found in Gaimardia, the only one capable of eliciting the mantle reaction to form an 'igloo-like' calcareous case, was metacercaria Gymnophallidae gen. sp. 1. This suggests that a process of recognition is taking place to allow such a definite reaction.

The size and form of the crystals of the calcareous covering of the metacercaria Gymnophallidae gen. sp. 1 are quite different to the normal shell structure of aragonite microcrystals (Figs 5b-e \& 6) (Taylor et al. 1973). These differences are likely related to changes in chemical composition of the organic matrix on which the deposition of calcium carbonate takes place. The organic matrix in which the crystals of the shell develop is currently considered to determine the initiation of crystal formation (nucleation), crystal orientation, crystal size and crystal type (Wilbur \& Saleuddin 1983). Recent investigations in Pomacea (Ampulariidae), reviewed by Watabe (1983), have demonstrated that the repaired shell matrix is different from normal, and this difference is accompanied by variations in the type and form of crystals of repaired shell. In Gaimardia trapesina the chemical nature of the organic matrix secreted by the altered outer mantle epithelium in the vicinity of the parasites (likely to differ to that secreted by non-altered epithelium) could determine differences in form and type of crystals of the calcareous coverings compared to those of the normal shell structure.

As the organic matrix is currently viewed as a determinant of the initiation of the crystal formation or nucleation (Wilbur \& Saleuddin 1983), the lack of deposition of shell material at the aperture of the calcareous coverings is likely related to the lack of organic matrix in this area (Fig. 3d).

According to Lauckner (1983) 'the most conspicuous reaction of marine bivalves to invasion by larval gymnophallids is the formation of pearls'. This is viewed as the host-cellular response against a foreign body that cannot be phagocytosed. Pearl formation 'constitutes a malformation resulting from the host's attempt to wall off an intruder which cannot be phagocytized or eliminated'. In contrast to this, in the case reported here, larva survivorship has been preserved throughout the evolutionary process of adjustment in the parasite life cycle, i.e. the parasites have successfully adjusted to the adversity imposed by the host (Esch \& Fernández 1993). Therefore, if the host reaction is not a non-directed attempt to eliminate a foreign body - the metacercariae in this case - the results of these reactions should be seen as a trait incorporated in the life cycle of the parasite.

Campbell (1985), describing the life cycle of Meiogymnophallus rebecqui (Bartoli, 1983), parasite of the bivalve Abra tenuis from Plymouth, found a host reaction similar in many ways to that observed in Gaimardia trapesina infected with Gymnophallidae gen. sp. 1. Metacercariae occur in the extrapallial space, and the host reaction involves the hyperplasia of the outer mantle epithelium adjacent to the larvae and the secretion of calcareous material (the so-called 'blister') around the parasite. The parasite, however, never becomes fully enveloped; a hole is present allowing the larvae to escape. When the host response is directed not to a single but to a group of metacercariae, a craterlike calcareous structure is deposited around them. The author considers these responses as additional protection against mechanical damage in the gizzard of the definitive host.

Fisher (1932) reported a malformation in Mya arenaria from Belfast Lough, Northern Ireland, consisting of a 'rised blister opening at the posterior end' (of the shells) located in the 'area enclosed by the deep sinus formed by the pallial scar'. In Lauckner's (1983) opinion these blisters could be assigned to a host-reaction in response to a massive invasion by trematode metacercariae. Despite the extremely brief description by Fisher (1932), the shell lesions described in M. arenaria are likely similar to the reaction observed in Gaimardia.

In our opinion, the term 'blister' should be restricted to the calcareous secretions with identical mineralogic composition than the inner shell surface, forming a complete covering of the larvae, i.e. without any opening, and to use the term 'calcareous coverings' to refer to encasements that always have an opening to allow the 'escape' of the larvae.

The reaction of Gaimardia trapesina in the presence of metacercaria Gymnophallidae gen. sp. 2 involves only the alteration (hyperplasia and metaplasia) of the outer mantle epithelium to delimit a large space between mantle and shell, where numerous larvae remain free. The result of the metaplastic process, i.e. a columnar epithelium, strikingly differs from that observed in the reaction to metacercaria Gymnophall- 
idae gen. sp. 1. A somewhat similar reaction to groups of metacercariae was described by Bartoli (1974) in Abra ovata infected by Meiogymnophallus rebecqui. However, in the case of G. trapesina, neither the occurrence of depressions or pits corresponding to the position of each larvae, nor the formation of mantle proliferation in the form of villosities, have been observed.

The structural changes observed in the outer mantle epithelium of Gaimardia trapesina adjacent to metacercaria Gymnophallidae gen. sp. 2 were similar to those described by Watabe (1983) during the mollusc shell repair process. According to Watabe (1983), in species of Anodonta (Unionidae) and Musculus (Mytilidae), for example, the cells of the outer mantle epithelium usually change their shape (becoming taller) while being progressively transformed into periostracum and prismatic layer-secreting-type cells. The author concludes that 'the function of the mantle is not permanently fixed, but can be altered by a stimulus such as a shell damage'. In this respect, the presence of larval digeneans between the mantle and the shell represent a stimulus comparable, judging from the alteration they elicit, to shell damage.

With respect to the metacercaria Lepocreadiidae gen. sp., the present record is the first from a mollusc in the Southwestern Atlantic Ocean. There are 4 lepocrediid metacercariae reported from different bivalve families (Veneridae, Mactridae, Donacidae and Cardiidae) (Bartoli \& Prévot 1978). The only reference to a host reaction is by Bartoli (1967) reporting a lack of response by several bivalve species parasitised by Lepocreadium pegorchis (Stossich, 1900). Moreover, only $L$. album Stossich, 1890 was found in the same habitat to the present lepocrediid metacercaria of Gaimardia trapesina.

Despite the irregular sampling intervals of the Gaimardia trapesina population at Ushuaia during 1997, there seems to be a clear seasonal variation in the prevalence and intensity of infection by Gymnophallidae metacercariae. Maximum values of prevalence and intensity of infection were seen in May and July (Table 2 ), coincidently with the period of maximum brooding activity of the bivalves. In contrast, no significant seasonal variation was evident in prevalence of infection by metacercaria Lepocreadiidae gen. sp.

The reproductive activity of Gaimardia trapesina does not seem to be affected by the presence of metacercariae, since most of the specimens from May and July samples, when maximal values of prevalence of infection were reached, showed embryos within both inner and outer demibranchs. This reflects normal gametogenic activity. Metacercariae infections do not provoke parasitic castration of the host (Lauckner 1983).
Acknowledgements. The authors express their gratitude to Dr Guido Pastorino for providing part of the studied material, and to Dr Silvia Ametrano for her valuable comments on mineralogy; thanks to Lic. Rafael Urréjola (from the MLP SEM unit) for technical assistance and to Mrs Lucy Shirlow for the revision of the English. The X-ray mineralogical analyses were made by Dr Daniel Poiré at the Centro de Investigaciones Geológicas (CIC - CONICET). C.F.I. and F.C. are members of the National Research Council for Science and Technology (CONICET).

\section{LITERATURE CITED}

Bartoli P (1967) Etude du cycle évolutif d'un trématode peu connu: Lepocreadium pegorchis (M. Stossich, 1900) (Trematoda, Digenea). Ann Parasitol Hum Comp 42:605-619

Bartoli P (1973) Les microbiotopes occupés par les métacercaires de Gymnophallus fossarum Bartoli, 1965 (Trematoda, Gymnophallidae) chez Tapes decussatus L. Bull Mus Hist Nat Zool 91:319-334

Bartoli P (1974) Recherches sur les Gymnophallidae F. N. Morozov, 1955 (Digenea) parasites d'oiseaux des côtes de Camargue: systematique, biologie et ecologie. Thése de Doctorat d'Etat, Université des Sciences Dáix-Marseille

Bartoli P (1978) Modification de la croissance et du comportement de Venerupis aurea parasité de Gymnophallus fossarum P. Bartoli, 1965 (Trematoda, Digenea). Haliotis 7: 23-28

Bartoli P, Prévot G (1978) Le cycle biologique de Holorchis pycnoporus M. Stossich, 1901 (Trematoda Lepocreadiidae). Z Parasitkd 58:73-90

Bowers EA, Bartoli P, Russell-Pinto F, James BL (1996) The metacercariae of sibling species of Meiogymnophallus including M. rebequi comb. nov. (Digenea: Gymnophallidae), and their effects on closely related Cerastoderma host species (Mollusca: Bivalvia). Parasitol Res 82:505-510

Bush AO, Lafferty KD, Lotz JM, Shostak AW (1997) Parasitology meets ecology on its own terms: Margolis et al. revisited. J Parasitol 83:575-583

Campbell D (1985) The life cycle of Gymnophallus rebecqui (Digenea: Gymnophallidae) and the response of the bivalve Abra tenuis to its metacercariae. J Mar Biol Assoc UK 65:589-601

Cheng TC, Rifkin E (1970) Cellular reactions in marine molluscs in response to helminth parasitism. In: Snieszko SF (ed) A symposium on diseases of fishes and shellfishes. Am Fish Soc Wash (Spec Publ 5):443-496

Cremonte F (1999) Estudio parasitológico de bivalvos que habitan ambientes marinos y mixohalinos en Argentina. Doctoral Thesis Facultad de Ciencias Naturales y Museo, Universidad Nacional de La Plata

Esch GW, Fernández JC (1993) A functional biology of parasitism. Chapman \& Hall, London

Fisher N (1932) Malformation in Mya arenaria L. J Conch 19:270

Gabe M (1968) Techniques histologiques. Masson, Paris

James BL (1964) The life cycle of Parvatrema homoeotecnum sp. nov. (Trematoda: Digenea) and a review of the family Gymnophallidae Morozov, 1955. Parasitology 54:1-41

Lauckner G (1983) Diseases of Mollusca: Bivalvia. In: Kinne O (ed) Diseases of marine animals, Vol II. Biologische Anstalt Helgoland, Hamburg, p 477-961

Martorelli SR, Morriconi E (1998) A new Gymnophallidae metacercaria (Digenea) in Nacella $(P)$ magellanica and $N$. $(P)$ deaurata (Mollusca, Patellidae) from the Beagle Channel, Tierra del Fuego, Argentina. Acta Parasitol 43:20-25 
Rios E (1994) Seashells of Brazil. Editora da Fundaçao, Universidade do Rio Grande

Szidat L (1962) Über eine ungewöhnliche Form parthenogenetischer Vermehrung bei Metacercarien einer Gymnophallus-Art aus Mytilus platensis, Gymnophallus australis n. sp. des Südatlantik. Z Parasitkd 22:196-213

Szidat L (1965) Los parásitos de los mitílidos y los daños por ellos causados. II. Los parásitos de Mytilus edulis platensis (mejillón del Plata). Comun Mus Argent Cienc Nat 1:1-16

Editorial responsibility: Albert Sparks,

Seattle, Washington, USA
Taylor JD, Kennedy WJ, Hall A (1973) The shell structure and mineralogy of the Bivalvia. II. Lucinacea-Clavagellacea, Conclusions. Bull Br Mus (Nat Hist) Zool 22:255-294

Watabe N (1983) Shell repair. In: Wilbur KM, Saleuddin ASM (eds) The mollusca, Vol 4, Part 1. Academic Press, New York, p 289-316

Wilbur KM, Saleuddin ASM (1983) Shell formation. In: Wilbur KM, Saleuddin ASM (eds) The mollusca, Vol 4, Part 1. Academic Press, New York, p 235-287

Submitted: February 14, 2001; Accepted: June 11, 2001 Proofs received from author(s): December 10, 2001 